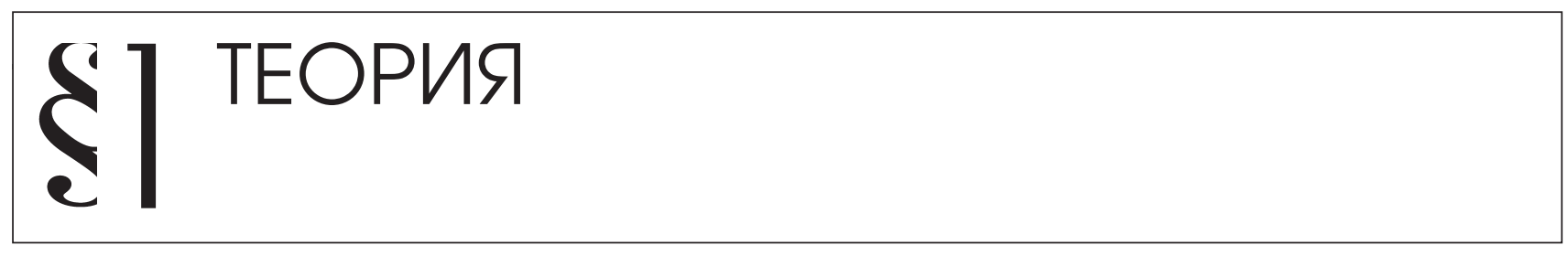

Chirkin V.E.

\title{
THREE GLOBAL LEGAL SYSTEMS OF MODERNITY: CONVERGENCE AND ANTAGONISMS
}

\begin{abstract}
The author examines the classifications of legal systems and legal families that exist in the Russian and foreign literature, and notices their inaccuracies. The terms "legal system" and "legal family" are often used interchangeably, different social essence of the major legal systems is ignored. Anglo-Saxon law and totalitarian socialist legal system are in the same classification unit. It is offered new approaches and synthesis. The author uses the historical, logical, deductive, inductive and comparative research methods, applies the formational-civilizational approach and, on this basis, identifies three major legal systems in the modern world: the Muslim system, liberal semi-social capitalist system and the totalitarian socialist system. On the basis of socio-culturological legal approach within each of the global systems, the author highlights the legal families. In the Moslem system there are fundamentalist (radical) and modernized (upgraded) legal families, but also for another reason - the Sunni and Shiite communities legal families, in the liberal semi-social capitalist system there are Anglo Saxon, the Romano-German and other families, in the totalitarian socialist system - orthodox Leninist-Bolshevik and modernized partly, upgraded (but only in the area of economic regulation) family.

Keywords: Administrative economic law, business law, geopolitics, banking law, the subject of economic law, the legal systems, Classification, The Muslim system, Liberal capitalist system, Totalitarian socialist system, Legal families, Comparative Law, Family Law, Islamic law, common law, Economics, law, economic law, investment law, customs law.

Аннотация: Автор исследует различные классификации правовых семей, разработанные как в российской так и в зарубежной науке права. Исследуется соотношение понятий правовая семья и правовая система. Исследуются отдельные особенности семей мусульманской, англосаксонской и других правовых семей. Проводиться сравнение англосаксонской и сочиалистической правовых семей. Исследуются основные источники права различных правовых семей (конституции, религиозные тексты и т.n.). Исследуются основные принципы функционирования различных правовых семей. Используются классические методы исследования используемые юридической наукой. Основным методом исследования является сравнительно-правовой метод. Применяется формально-цивилизационный подход. Автор выделяет три основных праовых семьи: мусульсанскую, тоталитарную (социалистическую), и либеральную. С помощью социо-культурологического подхода автор выделяет подвиды основных правовых семей. Так например мусульманская правовая семью подразделяется на радикальную и модернизированную правовые подвиды; либеральная правовая семья подразделяется автором на аннглсаксконсукую романо-германскую подвиды правовых семей.
\end{abstract}

Ключевые слова: Правовая семья, конституция, принципы, глобализация, сравнительный анализ, мусульманское право, англосаксонское право, романо-германское право, сочиалистическое право, либеральная правовая семья, тоталитарная правовая семья.

$\mathrm{n}$ each state there is its law, its legal system. These "country" systems are often similar, but often different and even fundamentally opposed by their social essence. Similar legal systems of individual countries are combined classifiers in legal families. It is not enough to penetrate the social essence of the phenomena. It is important to consider that a "country" legal system, a family are part of a global legal system, which has a decisive impact on their social and legal content.
The founders of a systemic approach to comparative jurisprudence (Rudolf Schlesinger (United States), Ernst Rabel (Germany), René David (France), Konrad Zweigert (Germany), Marc Ancel (France), Heinz Kötz (Germany), Rodolfo Sacco (Italy), Patrick Glenn (Canada), among others, created a new orientation to the investigation of law which enabled by means of mapping of different legal communities to more profoundly perceive the legal content. They usually used for such communities the terms "system" 
and "family" as synonyms and placed sometimes in a single classification category, for example, socially different the Romano-Germanic and socialist families (or systems) of law.

In our view in order to more fully analyze the interaction, convergence, and antagonisms in modern law of the countries of the world the concepts of legal system and legal family must be distinguished in scholarly studies and their correlation clarified. This would enable one to see more clearly the similarities and contradictions between the various legal communities and the paths of their convergence.

The term "legal family" combines a group of countries socially akin and identical in their principal legal institutes (for example, the Muslim law in the fundamentalist family in Oman, Saudi Arabia, and elsewhere, and the Muslim law in the modernizing family in the "advanced" Muslim countries: Egypt, Iraq, and others, (One should distinguish in Muslim law obviously such socially homogeneous Sunni and Shiite families, but we do not know the numerous peculiarities of these families and do not consider them) another example the Romano-Germanic and Anglo-Saxon families in contemporary capitalism. Using the example of China or to a certain extent of Vietnam, Cuba one may note that may be a special family with respect to the "modernized" socialist law is creating now, different from that which occurred before under the dictatorship of the proletariat and the prohibition of private property in the USSR and which exists now in North Korea.

Legal families in modern times have a global character. The Romano-Germanic (European continental law) operates in many countries of Africa (former colonies of France, Spain, and Portugal) and certain States of Asia and Latin America. Anglo-Saxon law is used in the United Kingdom, United States, and Australia. Muslim law, the shariat, (The Koran contains the teachings of the Prophet Mohammed written down after his death; the Sunna is the recollections of the behavior and conduct of the Prophet. The Shariat is the righteous path of social and personal life of Muslims. The provisions of the Korean and Sunna are the basis of the Shariat) operates not only in Saudi Arabia, Afghanistan or Indonesia but in certain relations in the multi-million Muslim communities of India, France, United States, and elsewhere. Socialist totalitarian law is applied on various continents (for example, Cuba and the Korean People's Democratic Republic).

The term "legal system" scholars usually use in individual state (country) meaning (system of law in Russia or in Germany, French or Japanese legal systems). There also is the concept "system of international law". However, it is evident from the above that the operation of Muslim, capitalist, or socialist law also has an international, global nature, the aforesaid countries being from different continents. Each of these legal communities has its own legal principles contained especially in constitutions (and the constitutions are the basic for the development of the legal system of a particular country). These principles are different, sometimes opposite, they are specific to Muslim communities, the modern liberal capitalism and totalitarian socialism (Another of socialism in the states yet, and we don't know exactly how it can be in terms of economic, social, political, ideological democracy), identified three groups of States and their law as three unity.

The principles contained in the Koran and Sunna which are inherent to Muslim law have traces of semi-feudal elements. Different principles operate in capitalist and socialist law. These under capitalism, for example, are: in the sphere of the economy - freedom and dominance of private ownership, freedom of the market and competition and others; in the political system of society - the power of the people, and not of a determined social class or class alliance, freedom to form and equality of political parties, replacement of parties in power by means of periodic universal and alternative elections, freedom of political opposition without using coercive means of struggle, formal equality of individuals, and so on), and in the spiritual life of society - ideological diversity, equality of ideologies, and the like.

Under socialism other legal principles operate - prohibition of private ownership under orthodox LeninistBolshevik socialism in the past and its modern interpretation in the Korean People's Democratic Republic and, to a lesser extent, in Cuba; dominance of socialist ownership (in China as well), irrespective of whether private ownership is permitted or not; prohibition against a free market, comprehensive State regulation, leading role of the Communist Party, prohibition of political opposition, system of soviets, preferences for persons relegated to the "working people", and the like.

These principles of law show also that each of the three said legal communities has its own social essence. Despite the processes considered below of a certain convergence with the law of capitalist countries, the family of law in the "advanced" Arab countries remains Muslim (In this case we do not get involved in the lengthy discussion about the formations and civilizations nor a discussion of the concept of socio-culture. We note merely that the first approach combines a conclusion of Marxism concerning socio-economic formations and a broad concept of civilization, and the second approach relies on methods of investigating civil, political, and legal culture). The incorporation in the constitutions of certain capitalist countries of norms on social justice, narrowing private ownership for public interests, or 


\section{Право и политика 8 (188) 2015}

State planning do not make such law socialist. The amendments of 1988 to 2004 in the 1982 Constitution of China and the introduction in the economy of certain capitalist methods of economy do not transform the socialist law of China into capitalist law. By virtue of its basic principles, it remains socialist, just as in the Korean People's Democratic Republic, Cuba, Vietnam, or Laos.

The principles of law (different in Muslim, capitalist, or socialist law) express the unity of the social essence of each of these legal communities and unites them much more deeply and strongly than the unity of the legal content of legal families belonging to one or another larger legal community,. These principles are the essence of the Muslim, Socialist or capitalist law, determine its content, its main leading legal institutions. Muslim law and capitalist and socialist law are not families, but global legal systems. Families, although they too are global, in terms of their content, there are "inside" respectively in each of the three global communities, and not arranged in parallel. These systems, just as the families within them and "country" systems of law, are not kindred among themselves, but different and, moreover, in certain of their basic provisions, but far from all, antagonistic (to be sure, in all systems there are identical legal institutes not relating to the essence thereof, not having social content, but necessary for legal regulation, including the technique thereof (for example, ownership, powers, rights, duties, responsibility, evidence). In any event we speak of law, and not of some other social phenomenon, and similarity of certain institutes thereof is inevitable.

It seems that when singling out in modern law, on one hand, global legal systems and, on the other, global legal families (religious legal systems of the past we do not consider here), one must use different methodological methods: an essence formative-civilization approach for systems (criterion of their social essence) and socio-culturologicallegal approach (the socio-cultural legal content thereof) as an element, one aspect of a civilization analysis - for families. Because each family is within its own system, the last approach incorporates in the characteristics of a family the essence and civilization characteristic as a whole, but is richer, taking into account various content, not only legal principles, but the diversity of legal linstitutes, legal technique, as a result of which this enables various families to be singled out on the base of the systems. We usually omit in the names of families their essence characteristic, for example, capitalist European continental family, although in the totalitarian socialist countries of Southern and Eastern Europe a socialist European capitalist family operated in the past. The 1951 Program of the Communist Party of Great Britain did not exclude the operation of basic political insti- tutes of Anglo-Saxon law (for example, parliamentarianism) under socialist (evidently not of a totalitarian character).

Among the said terms a general concept exists in doctrine only for a formation (socio-economic formation), but only in Marxism; other authors virtually never use it. Law has hundreds of definitions for the term of civilization, culture, socio-culture, and culturology. We use the concept of socio-economic formation as it formed in Russian doctrine (with the clarifications overcoming the excessive accent on the economy) and the concepts and characteristics of civilization as represented in the studies by the Russian (later American) author, Pitirim Sorokin, [1] the English historian, Arnold Toynbee [2], and the Russian authors, B. N. Kuzyk and Iu. V. Iakovets [3]. In order to single out families within formation global legal systems, we use studies on socioculture, and also the approach set out by Almond and Verba when studying civic, in essence political, cultures [4] and used by Legrand when studying law [5], but in this instance in the sphere of law socio-cultural is not identified in general and not socio-cultural civic or socio-cultural political, but socio-cultural legal content (socio-cultural content in its legal expression); this serves as the basis for singling out legal families within systems.

All the said approaches, if taken in isolation, have their shortcomings. The use of Marxist formation approach, as one of the elements of scientific analysis, may give reliable results, but it schematizes and distorts reality and sometimes leads to erroneous conclusions, rejecting the humanist significance of the experience of mankind before the creation of a socialist State "dictatorship of the proletariat", and then a "socialist all-people's State" (which was interpreted as the summit of political development until a certain stage - communism) and the emergence of socialist law. The civilization approach, objectively somehow linked with the formational (although it has its own social element distinct from the formational approach) takes into account many aspects which were ignored under the formational approach and identifies certain foundations for the establishment of varieties of legal families within the "essential systems". It enriches cognition, makes it more may-sided, rich, having regard to various aspects transcending only contrastive comparison inherent to a formal approach. But, all the same, it ignores the essence of a system which the formational approach identifies. Therefore we speak of combining them.

The socio-cultural legal approach to law and to the systems and families thereof has an even greater multisided and clarifying character. He gives a more profound impression about the strictly legal firmament of law in connection with the general culture of particular peoples or communities thereof. 
In our view the formational, civilization, and sociocultural legal study of systems and families of law and of legal reality in its broadest interpretation enriched by modern notions and clarifications is compatible. One does not exclude the other; all three approaches may be combined, and when taking into account the strong and weak aspects of each, may lead to true conclusions. Thus, in summary one may speak about the use of a formational-civilization approach (if the socio-cultural approach incorporates the civilization approach). If one parses this in greater detail, the approach to the identification of modern global (and possibly other) systems and families of law might be called the formational-civilization socio-legal approach. This sounds rather complex from the standpoint of language, but enables the nature of the systems (including "country") and families to be identified in a complex that incorporates different countries.

In our view three global systems of law exist at present, differing in their formational, basic essence-civilizational, and socio-legal qualities: the Muslim legal system (the exist about twenty Muslim States, according to sundry data about one to 1.6 billion people live under the operation of Muslim law); the liberal-post social capitalist system (about four billion persons), and the system of law of totalitarian socialism (about 1.5 billion persons, more than one-fifth of humanity living in Vietnam, China, Korean People's Democratic Republic, Cuba, and Laos).

The particular aggregate of legal families of which the founders of a systemic study of law spoke are part of a certain global system and therefore families have the same essence as the systems of which they are a part, but within the systems they differ from one another in content, socio-cultural legal character, those aspects of civilization which under the unified essence of a particular civilization conditioned by formational indicia characterize multivariations, multi-colored nature of the content thereof. For example, ancient Greek and ancient Roman civilizations are relegated to slave-owning formation and civilization of Europe, and remote Japan during the period of the Middle Ages, to feudal, and so on.

Because the essence of legal families within "their own" system is the same, the mutual influences of legal families relegated to the same essence legal system (formational system) lacks antagonisms. To be sure, legal institutes penetrating from another family disturb the legal continuity and internal coordination of law and encounter resistance (for example, the penetration of the German concept of juridical person into English law met resistance in British courts). Nonetheless, such penetration may change certain institutes of a legal family, individual aspects of its legal content, but they do not break down the formational essence of the family subjected to legal pressure from without and do not (and cannot) change the essence of a particular global legal system (even constitutional recognition of private ownership and, the more so, its important role in the economy have not changed the formational (socialist) essence of Chinese law).

The mutual influence noted and perception of legal institutes of another family or system of law is especially evident on the evolution of constitutional law (this has special significance for classifications, because this branch consolidated principles of law), but convergence is common in other branches of law. Mutual influence is observed between the Anglo-Saxon and European continental families belonging to the system of liberal post-Socialist capitalist law and between various systems of the Muslim system. To be sure, new institutes which penetrate into another kindred family are incorporated into it by taking into account the peculiarities of the State and its individual legal system. The simple implementation in the law of the United Kingdom in 1998 of the provisions of the 1950 European Convention on the Protection of Human Rights and Fundamental Freedoms may serve as an example which did not encounter legal rejection (until this time many human rights were regulated in the United Kingdom by judicial precedents) or the penetration into Anglo-Saxon law (especially in the United Kingdom itself) of the concept of a juridical person used together with the traditional concept of the corporation, and the last concept is penetrating the countries of the continent, including Russia.

On the other hand, although the use by English practice of judicial precedents is officially denied in European continental law, this sometimes is manifest in some form on the continent, which is natural: the decisions of the highest courts (especially supreme courts) always has special authority. The strong influence of various families of law on the members of the European Union is linked with legal acts of the organs of the European Union, especially with regulations of direct effect which cannot be changed by European Union members (directives of the European Union also are binding, but members may choose the means of their implementation). These acts make uniform large institutes of law of the European Union countries (for example, Regulations "On the Law Applicable to Extracontractual Obligations" of 11 July 2007, No. 864/2007; the Regulation "On the Law Applicable in Contractual Obligations", of 17 June 2008, No. 503/2008). Harmonization of families and their institutes can, to be sure, within certain limits occur in legal families related in their essence. We already have spoken about the juridical person and corporation in continental law (including Russia) penetrating the Anglo-Saxon 


\section{Право и политика 8 (188) 2015}

thesis concerning the possibility of criminal responsibility of not merely natural, but also juridical, persons. Acts of other European organs (for example, judgments of the European Court for Human Rights) influence other families of law.

In the Basic nizams of the fundamentalist family and constitutions of the "advanced" Muslim countries the principles of the Koran and Sunna have identical irreproachable force and say that the principle source of legislation is the Shariat and when deciding questions the principle of ash-shura is used (especially meetings and discussions before achieving consent). Basically the same principles apply in respect of "infidels".The Koran and the Sunna are officially considered to be the constitution of the State in fundamentalist countries, although with regard to the interpretation of certain provisions of the Koran (especially the provision of principle with regard to power), the Sunni family (the majority of Muslims) and the Shiite family even in an orthodox approach both families are not identical. In countries of Muslim fundamentalist (Bahrain, Iran, Kuwait) constitutions have emerged (which is contrary to the above norm). The adoption in other countries of Muslim fundamentalism of Basic nizams (Oman, Saudi Arabia, United Arab Emirates) similar to constitutions also undermines certain Koranic principles. The fundamentalist family is converging with the modernizing family of Muslim law, where there has long since been a constitution and elections (partial elections to local agencies of individual suburbs of the capital were first held in 2005 in a country of fundamentalist Islam - Saudi Arabia, although officially in a fundamentalist family instead of deniable elections the Koranic principle of choice to participate in management by "authoritative" male Muslims (ash-shura) which are visible to the Umma - the Muslim community.

По другому основанию, видимо, можно выделить в мусултьманском праве суннитскую и шиитскую семьи.

The mutual influence of single-type legal families is in some measure noticeable. More complex is relations with global legal systems (Muslim, liberal post-social capitalist and the legal system of totalitarian socialism). Possibly the noted movements in the Muslim system contain the influence of other legal systems, especially the liberal-post social capitalist, but in the most fundamentalist countries this is resolutely denied, the said facts of the adoption of certain institutes of other systems is merely a coincidence. As regards jurists of the "advanced" Muslim countries, they, especially the Lebanese author, C. Marrat, acknowledge the possibility of the compatibility of institutes of Muslim and European law [6].

The mutual influence of different global systems, just as families, also cannot be denied, but systems, unlike single- type families, differ not only in their content, but in their social essence. The Muslim system, despite material changes in the "advanced" countries (republic instead of monarchy, elections, parliament, and so on) have as their foundation semi-feudal principles of the Shariat which have not been subjected to new interpretation over time (for example, the constitutions make provision for the equality of women, but "according to the Shariat", and the Shariat rejects such equality in principle (Certain modern Muslim jurists acknowledge that the Shariat contains provisions of varying meaning which are used for extremism. In this connection, in May 2012 the International Conference of Theologians from 23 countries was held and gave modern interpretations to controversial concepts of Islam - takfir (accusation of not believing in Islam), jihad, which is unilaterally interpreted as a declaration of war against "unbelievers"; the idea of an ecumenical Chalifate, and certain concepts of Islam. Pursuant to the results of the Conference, on 30 May 2012 a fatwa was not adopted (a binding opinion of the mujtahids who have the right to autonomously interpret the Koran), but a Declaration ("scientifically-substantiated document") explaining the incorrectly understood provisions of Islam which are used by certain forces, including to commit terrorist acts. The conclusions of the Conference contained eighteen points which interpret the content of certain provisions of Islam and the Muslim system of law. Among them: Islam prohibits to spill blood and cause wounds; jihad is multifaceted and does not reduce to armed acts, and an order for a military jihad can be given only by a lawful ruler; a Caliphate cannot be created on the territory of a sovereign State; infringements against the human life and property cannot be justified by the fact of their nonbelief; an accusation of non-belief and the severe consequences of this is only the right of Allah; even muztahids do not have the right to advance a takfir against someone; one cannot obstruct non-Muslims peacefully living among Muslims; a display of friendship towards them is not prohibited in Islam (for example, assistance to the sick, and so on). However, proponents of radical Islam do not accept these interpretations).

Along with the fundamentalist (radikalist) and modernized legal families in Muslim law on another base of the division there are Sunni and Shiite legal family. In 2015, the Shiites (husity) rebelled and overthrew president-Sunni (in almost all countries where Islamic fundamentalism in power are monarchs-Sunni). Modern capitalism differs from the past by its welfareism (sociality), and in this is converging with the socialist totalitarian system of law, but the legal system thereof is not completely social, and under conditions of a capitalist system, where the main principle is the dominance of private ownership and the principal stimulus 
is the aspiration to maximum profit cannot be fully social (a completely social legal system is possible, obviously, but so far is a social system unknown to us). Under modern capitalism the distribution of the social product is, as before, effectuated not in proportion to ownership (capital) and labor, but with enormous preferences for the first. Although in the leading capitalist countries developed social legislation exists, and the share of labor in the cost of manufactures, work, or services comprises about 70 to $80 \%$ (under totalitarian socialism, much less, and in modern Russia, also less), the oligarch-owner under capitalism receives revenues per month hundreds of thousands times more than the highest skilled worker and employee - the "white crow". The correlation of revenues of the $10 \%$ richest and $10 \%$ poorest in 2013 were as follows: the difference in Sweden was six times (the smallest difference in the world); in Italy - nine times; in Chile - fourteen times; in the United States - fifteen times. In countries on the periphery of capitalism, the difference is greater: in Zimbabwe, for example, eighty times. In Russia, with its complexities en route to capitalism, according to some economists, which significantly differ from the official data, 45 times.

With a general standard of living which is not high, Russia occupies third place in the world in the number of dollar millionaires (4.2 times higher per capita than in the world as a whole). The annually published declarations of revenues of certain major bureaucrats (including members of the Government, governors, members of the Federal Assembly) and certain of their highly-talented wives shows that such revenues from each spouse sometimes achieve about 300 million rubles per year (in some instances, more); that is, about one million rubles per day, which is approximately 300,000 times more than the average per capital revenue in the country and not comparable with the revenues of the basic population (the living minimum per capita of the population established by Decree of the Government of the Russian Federation during the first quarter of 2014 was 7,688 rubles per month (about US\$220) [7].

One also should take into account that of the approximately four billion persons living within the liberal-post socialist system, the majority are not in developed, but in developing, economically-backward countries. For this reason we call such a legal system semi-social.

Under any capitalist system, a very social system does not exist and on the basis of its principles cannot exist where measures of labor and measures of consumption are in conformity with one another. In socialist experience of the last the level of social equality was much higher, but it was maintained artificially, by the force of State power, and did not succeed.
Within the framework of the liberal semi-social capitalist system, the mutual influence of the family thereof is effectuated comparatively easily. But this system itself is categorically opposed to the influences of Muslim law born in that socio-economic formation which overthrew the bourgeois revolutions of the seventeenth and eighteenth centuries. There cannot be any harmonization between these systems, although the convergence of the modernizing family of Muslim law with the capitalist system, and sometimes with the socialist system of law (to be sure, outwardly in connection with the slogans of a socialist orientation in some Muslim countries) may occur to some extent. It is difficult to find constitutional institutions of classical Muslim constitutional law ("law of authoritative norms") which would be accepted by other systems. Perhaps one might be the principle of discussions until reaching consensus (the element of ash-shura) instead of voting.

Convergence, but not harmonization, is possible between the modern capitalist legal system and the modern socialist system. In this case the process has a bilateral character. Under modern conditions internal changes are occurring in the legal systems of capitalism and socialism. Possibly in individual countries of totalitarian socialism a new, somewhat modernized, family is emerging. It differs from that orthodox legal family which existed, for example, in the USSR before 1936 (adoption of the 1936 USSR Constitution) and then before the 1977 Constitution, which made changes in certain orthodox principles of Marxism-Leninism (proclaimed an all-people's State in place of the dictatorship of the proletariat and established that the Communist Party operates within the framework of the Constitution); instead of class power of the proletarian, the 1997 USSR Constitution proclaimed the power of the people. Certain changes occurred in the USSR thereafter (especially during the perestroika period from 1985), but the legal family of socialism (including in foreign countries which arose after the Second World War) until the choice of a different path of development by countries remained as before it its formation essence. It remains such now, even if a new family is being born within this system.

The contemporary changes in the existing countries of totalitarian socialism relate chiefly to the sphere of the economy. They do not affect (or do so very slightly) the political system, or the dominance of Marxist-Leninist ideology (with national specific features), but they are material and have a factual nature, and radically are changing the way of life in the country. Amendments made to the Constitution of China in 1982 and between 1988 and 2004 introduced such provisions which traditionally were rejected by the orthodox socialist family of law. The amendments establish 


\section{Право и политика 8 (188) 2015}

not only the admissibility, but the advisability, of private ownership, private entrepreneurship, speak of a "socialist market economy", the natural rights of man, a rule-of-law State, instead of the power of the class the term power of the people is used, and mention of the dictatorship of the proletariat is excluded from the Preamble.

This are major innovations. However, unlike the differences between legal families within the same system, the basis of the differences between the three named global legal systems are not only substantive, legal-socioculturological, and legal-civilizational, but are differences more profound, emanating from differences of principle, of social essence and of socio-economic formations. Therefore, in relations of such legal systems there are not only differences, but contradictions, antagonisms. These systems may to some extent converge, but they are irreconcilable, as are their families within different global systems.

Under these circumstances the questions concerning the mutual influences of global legal systems, and also legal families within different systems, concerning the forms and limits of mutual influence are resolved differently than in relations with kindred legal families. In general form one can merely say that such mutual influences $n$ the said systems do not reject and cannot reject or change the essential, formation foundations of the system. However, practice shows that sometimes such influences are so profound that certain essential aspects of the system are affected. Examples may be the aforementioned different attitude in principle in modern countries of totalitarian socialism towards private ownership - repudiated in principle by Marxism - or, on the contrary, the addition of the principle of formal legal equality in the capitalist system by the principle of social justice, which always was considered to be a major aspect of the Marxist-Leninist approach to the statute of the person, the State, the social system, and law and was not accepted by the capitalist system of law These examples show that unlike the processes of the unilateral convergence of some Muslim families with other global legal systems, the convergence of the modern capitalist and socialist systems of law is of a bilateral nature.

We have mentioned above the legal principles of different systems and certain modifications thereof, which is most starkly demonstrated by the convergence of systems in process, and likewise by their antagonisms. We shall add certain details, but of a general nature.

One of the distinctions of principle in legal regulation in capitalist and socialist legal systems from the very outset was the question of private ownership. For the former, private ownership was the foundation of economic and social relations, the freedom of the private owner was proclaimed, and ownership was declared to be "sacred and inviolate" (Article 17, French Declaration of the Rights of Man and Citizen). In the legal system of orthodox socialism, first created in Soviet Russia, private ownership in accordance with the Marxist-Leninist approach was regarded as a basic evil from which class inequality and other misfortunes emanated. It was legislatively prohibited and in practice in the Soviet Union actually eliminated. The Constitution authorized only socialist ownership of the means of production in two of its forms (State and cooperative-collective farm), and also personal ownership to articles of life, household, and consumption (only in large cities were one-person private hairdressers, photographers, and other subsidiary occupations preserved, but without the use of hired labor). There also were collective farm markets, where surplus agricultural products were sold by collective farm members or collective farms. Non-labor revenues were prohibited (Article 13, 1977 Constitution). The 1936 and 1977 Constitutions of the USSR and the constitutions of other socialist countries (Albania, Bulgaria, Hungary, Romania, and others) established the inequality of forms of ownership, and State ownership was declared to be higher. The basic objects of the economy were in exclusive State ownership. Virtually the entire economy in the USSR was statized. Such regulation, although in a somewhat softened variant, existed in the other countries of totalitarian socialism.

The modern constitutions of countries of totalitarian socialism permit private ownership. In some of them this exists to a limited extent (Korean People's Democratic Republic; somewhat broader in Cuba), and in others, especially China, large objects of private ownership exist, there is a significant private sector in the economy, and there are many dollar billionaires (in Vietnam the first such billionaire appeared only in 2010). In the course of the further development in the constitutions amendments were made and it was provided that private ownership not only is permitted, but is an important and essential addition to socialist economic management.

On the other hand, the status of private ownership changed in the legal system of modern liberal-social capitalism. For the first time derogations were made from the principles of the exclusive role and absolute freedom of private ownership in the 1919 Weimar Constitution of Germany. Instead of the former conception of unlimited private ownership, a formula was introduced that private ownership obliges, that it must perform a social function. Later this approach was reiterated in the 1949 Basic Law of Germany and in certain new constitutions of Latin American countries. In capitalist countries it is now con- 
sidered that private ownership should not serve the owner, but also be used in the interests of society.

Some new constitutions of capitalist countries have accepted the provision concerning objects of exclusive State ownership. To be sure, the major objects of the economy are not relegated to this category, although some of the said objects have special significance under the specific conditions of certain countries (for example, the seacoast and beaches in Italy and Spain).

One problem in the sphere of economic regulation which is irreconcilably divided the two legal systems here considered is the question concerning the approaches to the management of the economy. The freedom of entrepreneurial activity, freedom of competition, prohibition against monopolism, and a market economy always underlay the capitalist system. Orthodox socialist constitutions consolidated the statization of the economy, the centralized and directive management thereof, State monopoly of the administration of the economy, and statization of production and distribution. The State plan adopted in the form of a law with the possibility of criminal punishment for executives who did not fulfill it and material punishment for workers (deprivation of bonuses or increments to earnings) was the foundation of management activity. The principle of State planning of the economy was consolidated in constitutions. Centralized distribution existed of goods and services. The market was condemned as production anarchy and repudiated.

Contemporary constitutions of the countries of totalitarian socialism now speak of a market economy of a special type ("socialist market economy" - Article 15, 1982 Constitution of China, with subsequent amendments). To be sure, the former accent on the role of the State remains: a market economy "the State implements", provides the Constitution of the Chinese People's Republic (Article 15).

On the other hand, the doctrine of capitalist countries has long since (since the times of the English economist, John Maynard Keynes (1883-1946), spoken of the need for the participation of the State in economic regulation (including legal). This finds reflection in the constitutions of the countries of Europe (Spain, Portugal) in the recognition of the need for State planning of the economy and the adoption of State plans for the development of the country in a number of other capitalist countries. To be sure, unlike countries of totalitarian socialism, such plans have not a directive, but an indicator (orienting) character, but in principle the idea of State planning of the economy is accepted by the legal system of contemporary capitalism.

In the domain of constitutional regulation of social relations from the outset the two legal systems here considered shared an approach to the concept of "people" who comprised the system. The constitutions of capitalist countries spoke especially about the people as the single aggregate of individuals, the decisive part thereof being the electorate (citizens having the right to vote). The people were not divided in the constitutions into classes; the words working class, peasantry, exploiting class, working people, and exploiters were completely alien to such constitutions. The concept of "people" was rejected in the orthodox legal system of totalitarian socialism. It was believed that this word "people" masks, or conceals, in the interests of the ruling class of bourgeoisie, the real situation: class antagonisms in capitalist society and in the early stages of building socialism. Instead of the concept people in the constitutions of totalitarian socialism the names "working people" and "exploiters", "workers and peasants", "bourgeois and proletarian classes" (and also the stratum of the intelligentsia), labor and exploitative classes, the leading class in society being declared to be the working class. This status was consolidated in the constitutions. The concept of the power of the people was rejected; the power of workers and peasants, the dictatorship of the proletariat, was spoken of.

The power of the people was proclaimed from the beginning in capitalist law, but in modern constitutions of capitalist countries often it is proclaimed together with the working people (1947 in Italy; 1988 in Brazil, and elsewhere), that special power belongs to them in society, defense of the interests of the working people, and the significance of labor. Even the 1992 Basic nizam of Saudi Arabia contains a provision that ownership, capital, and labor (note most) comprise the foundations of society. To be sure, the understanding of working people in a legal system of modern capitalism is different from that in a socialist system: entrepreneur, capitalist, or "bourgeois" defending socially-useful labor (for example, enterprise management) also are working people from the standpoint of the system of capitalism. On the other hand, the 1977 Soviet Constitution, the provisions on the power of the people has included, and the constitutions of modern countries of totalitarian socialism now speak about the people (together with classes), the power of the people. Indeed, these formulations are construed in their own way, and the previous clichés about dictatorship are sometimes retained. Simultaneously with the provisions on the power of the people, the Constitution of China mentions a "democratic dictatorship".

As a result of mutual influences (and also the role of international law), approaches have changed to human rights. The constitutions of orthodox socialism did not recognize the natural rights of man (they mentioned only the rights of citizens given by the State), and the constitutions of the 


\section{Право и политика 8 (188) 2015}

capitalist legal system did not know socio-economic rights (except for the right of private ownership) and were silent about the duties of man and citizen (later they referred to such duties, such as the duty to pay taxes). The majority of the constitutions of capitalist countries at present contain norms on socio-economic rights of citizens (the influence of socialist constitutions and the 1966 International Covenant on Economic, Social, and Cultural Rights have a material influence here), and sometimes about duties; whereas the constitutions of the countries of contemporary totalitarian socialism mention human rights, although the principal emphasis is on the rights of citizens given to people by the socialist State.

The separation of powers was initially rejected decisively in the constitutions of the countries of totalitarian socialism, being replaced, pursuant to Marx, by the "prosaic division of labor". Instead of the concepts of legislative, executive, and judicial power these names were used: agencies of State power, agencies of State administration, agencies of the court, procuracy agencies. In essence this approach is now present in the constitutions of the modernizing legal system of totalitarian socialism. However, in recent years by means of amendments to the constitutions of certain countries mention was incorporated of the separation of powers. On the other hand, new branches of State power (electoral, control, civil) have emerged in the law of the countries of liberal-social capitalism and the sharp division of legislative and executive powers has been abolished; delegated legislation exists (acts having the force of a law issued by the Government on behalf of parliament) and regulatory power or so-called regulatory legislation (acts of this type are issued by the Head of State without such power in each case on the basis of general provisions of the constitution). Officially, these acts are not called laws, but actually they are laws in the name of executive power.

Several legislative organs have emerged in the countries of liberal-semi-social capitalist system (first having been established in the struggle against "bourgeois parliamentarianism" in Soviet Russia and existed until 1936). In Italy, Portugal, Brazil, Greece, and certain other countries laws are issued not only by parliament as a whole, but by certain of its permanent profile committees or commissions or permanent sections of parliament created for this. To be sure, such laws are issued on less important questions (the constitution provides for such a list) on behalf of the parliament itself and, for example, in Italy one-tenth of the members of parliament or a commission or committee may prevent this (not agree).

These innovations are hardly linked only with the influence of the legal institutions of totalitarian socialism. These innovations in the countries of capitalism were caused by the rapid acceleration of social development, when a slowlyworking parliament often did not keep up with the pace of life. However, the impact of law-creation practice in the socialist legal system is not to be excluded in this instance.

Orthodox socialist doctrine rejected the concept of the rule-of-law State. It was said that the State itself issued and repeals legal acts, laws, creates law (now therefore some French writers express careful doubt with regard to the conception of a rule-of-law State) [8]. Socialist literature is not always taken into account when doing so, that ultimately the actions of a State were conditioned by the requirements of social life and it was not taken into account at all that the State is bound by law: legal acts issued by the State and its agencies are binding upon the State; they oblige the State. So long as such are not repealed, the State and its agencies are bound to follow and perform them.

Now the situation has changed somewhat. In the texts of certain constitutions of the modern countries of totalitarian socialism there is mention of the rule-of-law State. However, the realization of this principle cannot be fully effectuated given the operation of another more important principle the leading role of the Communist Party in society and the State. The key principle of the Soviets as the only public authorities at all levels of the territorial organization of the State also stored, local self-government is not recognized..

We have named several examples of the mutual influence of global legal systems which differ in principle in their essence. There are other facts, and they require further research. However, the examples cited show that the mutual influence of antagonistic systems may be and is effectuated only to a certain extent and to a certain degree, in specific forms. Antagonistic systems cannot simply be merged without a transformation of their essence. The liberal-social system of capitalism cannot accept, for example, the principles of the dominance of socialist ownership in the economy, or the role of the Communist Party, or democratic centralism, or the idea of the system of soviets instead of local self-government, or the binding nature of Marxist-Leninist ideology (now with a national specific feature, for in China the ideas of Mao Tse-tung and Deng Xiaoping; in Cuba, of Jose Marti; and in Vietnam of Ho Chi Minh; among others), authoritarianism and personality cult of State power. The legal system of totalitarian capitalism cannot accept capitalist principles as its foundation so long as it remains socialist. Otherwise it ceases to be such.

The said three global legal systems have antagonistic qualities, but in all instances this is law. They have identical legal institutions, and this cannot be otherwise. Some of them donot have a clearly expressed social character; for example, relating to the independent-work contract or 
the contract of purchase-sale. Mutual influence exists. To deny this, as was previously done in Soviet doctrine, is impossible. The examples adduced affirm this. A certain convergence also is occurring (including on the part of one family of Muslim law), which has been demonstrated above. However, this is the convergence of only certain elements of a particular global legal system. This is far from harmonization, elements of which are observed in some families of law belonging to the same global legal system.

The convergence of global legal systems is growing, but this has its objective limits. So far in Muslim, liberal- capitalist, and totalitarian socialist systems (especially in the orthodox families of the first and third) there are constitutional provisions which can never be accepted by other systems because such provisions are irreconcilable, antagonistic. And if there are such provisions in constitutions, they permeate other branches of law, precluding their harmonization. Their formation-civilizational principles cannot be changed, lost, accepted by another global legal system; otherwise, the system transforms into another, that is, ceases to exist. And then we are speaking about entirely different processes.

\section{Библиография:}

1. Сорокин П. А. Человек. Цивилизация. Общество //Общ. ред., сост. и предисл. А. Ю. Согомонов: Пер. с англ. М.: Политиздат, 1992. [Sorokin P. A. Man. Civilization. Society], ed. A. Iu. Sogomonov (1992).

2. Тойнби А. Постижение истории. М. 1991. С.731 \{А. Тоynbee, Comprehension of History] (1991\}.

3. Кузык Б.Н., Яковец Ю.В. - Цивилизации: теория, история, диалог, будущее. 6 томов. [2006-2009, PDF, RUS]; Кузык Б. Н., Яковец Ю. В. Цивилизации: теория, история, диалог, будущее // Т. III: Северное Причерноморье - пространство взаимодействия цивилизаций. - М.: Институт экономическихстратегий, 2008. - С. 18. [B. N. Kuzyk and Iu. V. Iakovets, Civilization: Theory, History, Dialogue, Future/ (2006-2009), III].

4. Almond $\mathrm{G}$ and Verba S. The Civil Culture .Princeton.1963

5. Legrand P. Fragment on Law-in-Culture. P.1999; LEGRAND P. Le droit comparé, P., 4ème édition, P.2011.

6. The Oxford Handbook of Comparative Law/ ed. by M.Reimann, R.Zimmermann. Oxford. 2008.P.631.[ See M. Reimann and R. Zimmermann (eds.), The Oxford Handbook of Comparative Law (2008), p. 631.]

7. Российская газета [Russian Newspaper], 1 July 2014.

8. Hamon F., Troper M. Droit constitutionnel.30e éd.; 2007, p. 79. См.: Тойнби А. Постижение истории. М. 1991. С.73

9. Петрова Г.В. Международное финансовое право: учеб. для вузов. - М.: Юрайт; Высшее образование, 2009. - С. 15, 16.

10. Лисовский В.И. Сущность и система международного финансового права // Сов. ежегодник международного права (1964-1965). - М.: Наука, 1966. - С. 134, 135.

11. Лисовский В.И. Международное торговое и финансовое право. - М.: Высшая школа, 1974.

12. Веральский М. Рец. на кн.: Шпиллер Г. Валютная монополия и международные финансовые отношения // Finance. 1963. - № 3.

13. Ровинский Е.А. К вопросу о предмете международного финансового права // Труды ВЮЗИ. - М., 1967. - Т. 9. Вопросы советского финансового права.

14. Ровинский Е.А. Международные финансовые отношения и их правовое регулирование // Сов. государство и право. 1965. - № 2. - С. 60-68.

15. Винницкий Д.В. Международное договорно-правовое регулирование и современное бюджетное право // Очерки бюджетно-правовой науки современности: монография / под общ. ред. Е.Ю. Грачевой и Н.П. Кучерявенко. - М.; Харьков, 2009.

16. Альтшулер А.Б. Международное валютное право. - М: Международные отношения, 1984.

17. Попондопуло В.Ф. Международное коммерческое право. - СПб., 2004.

18. Вельяминов Г.М. Международное экономическое право и процесс (Академический курс) : учеб. - М.: Волтерс Клувер, 2006.

19. Шумилов В.М. Международное финансовое право: учеб. - 2-е изд. - М.: Международные отношения, 2011. - С. 27.

20. Международная финансовая система: вызовы XXI века: монография / ред., пер. М.А. Шаповалов. - М.: Буки Веди, 2013. - C. 14.

21. Петрова Г.В. Международное финансовое право: учеб. для вузов. - М.: Юрайт; Высшее образование, 2009. - С. 17.

22. Шумилов В.М. Международное экономическое право: учеб. - метод. пособие. 2-е изд. - М.: ООО ИКК «ДеКА», 2002. - С. 42.

23. Рукавишникова И.В. Метод финансового права: автореф. дис. ... д-ра юрид. наук. - Саратов, 2004.

24. Элькинд П.С. Сущность советского уголовно-процессуального права. - ЛГУ, 1963. - С. $91,92$.

25. Алексеев С.С. Выражение особенностей предмета советского гражданского права в методе гражданско-правового регулирования. Виды гражданско-правовых отношений и метод гражданско-правового регулирования // В кн.: Антология уральской цивилистики. 1925-1989 : сб. ст. - М., 2001. - С. 155, 156.

26. Протасов В.Н. Что и как регулирует право: учеб. пособие. - М, 1995. - С. 40.

27. Общая теория государства и права / под ред. М.Н. Марченко. - М., 1998. - Т. 2. - С. 238.

28. Таможенное право: учеб. / отв. ред. А.Ф. Ноздрачев. - М., 2007. - С. 42, 43.

29. Таможенное право: учеб. для вузов / под общ. ред. Б.Н. Габричидзе. - 5-е изд. перераб. и доп. - М., 2004. - С. 139 - 145.

30. Сандровский К.К. Таможенное право. - Киев, 1974. - С. 19. 
DOI: $10.7256 / 1811-9018.2015 .8 .15673$

При цитировании этой статьи сноска на dоі обязательна

\section{Право и политика 8 (188) 2015}

31. Бакаева О.Ю., Матвиенко Г.В. Таможенное право: учеб. / отв. ред. Н.И. Химичева. - М., 2004. - С. 27 (автор главы - О.Ю. Бакаева).

32. Марков Л.Н. Таможенное право СССР. - Иркутск, 1973. - С. 24, 25.

33. Бахрах Д.Н., Кивалов С.В. Таможенное право России. - Екатеринбург, 1995. - С. 6, 7.

34. Астафуров Н.В. Правовое регулирование государственных и муниципальных расходов: дис. ... канд. юрид. наук. Волгоград, 2009.

35. Ц Цыренжапов Ч.Д. Правовые основы государственных и муниципальных расходов: дис. ... канд. юрид. наук. - Томск, 2005.

36. Нерсесянц В.С. Философия права. - М., 2006. - С. 33.

37. Ефимова Л.Г. Банковское право : учеб. и практ. пособие. - М.: Изд-во «БЕК», 1994. - С. $4,5$.

38. Егорова Л.Ю. Проблемы защиты публичных интересов прокурором в гражданском и арбитражном судопроизводстве : дис. ... канд. юрид. наук. - М., 2006. - С. 46.

39. Софиенко М.Б. Правовая свобода как способ реализации индивидуальной свободы в социальной системе : дис. ... канд. филос. наук. - Томск, 2007. - С. 28-30.

40. Макиндер Х.Дж. Географическая ось истории // Полис. - 1995. - № 4.

41. Ратцель Ф. Человечество как явление жизни // В кн.: История человечества. - СПб., 2003. - С. 108, $138-153$.

42. Ершов В.В., Ашмарина Е.М., Корнев В.Н. Экономическое право и экономическая теория // Государство и право. - 2015. - № 1. - С. 57-71.

43. Ершов В.В., Ашмарина Е.М., Корнев В.Н. Экономическое право: сравнительно-правовой анализ Германии, Франции, Китая и России // Государство и право. - 2014. - № 9. - С. 53-64.

44. Шумилов В.М. Международное финансовое право : учеб. - М.: Международные отношения, 2005. - С. $42-45$.

45. Шумилов В.М. Международное финансовое право : учеб. - 2-е изд. - М.: Международные отношения, $2011 .-$ С. 100.

\section{References (transliterated):}

1. Sorokin P. A. Chelovek. Tsivilizatsiya. Obshchestvo / /.Obshch. red., sost. i predisl. A. Yu. Sogomonov: Per. s angl. M.: Politizdat, 1992. [Sorokin P. A. Man. Civilization. Society], ed. A. Iu. Sogomonov (1992).

2. Toinbi A. Postizhenie istorii. M. 1991. S.731 \{A. Toynbee, Comprehension of History] (1991\}.

3. Kuzyk B.N., Yakovets Yu.V. - Tsivilizatsii: teoriya, istoriya, dialog, budushchee. 6 tomov. [2006-2009, PDF, RUS]; Kuzyk B. N., Yakovets Yu. V. Tsivilizatsii: teoriya, istoriya, dialog, budushchee // T. III: Severnoe Prichernomor'e - prostranstvo vzaimodeistviya tsivilizatsii. - M.: Institut ekonomicheskikhstrategii, 2008. - S. 18. [B. N. Kuzyk and Iu. V. Iakovets, Civilization: Theory, History, Dialogue, Future/ (2006-2009), III].

4. Almond G and Verba S. The Civil Culture .Princeton.1963

5. Legrand P. Fragment on Law-in-Culture. P.1999; LEGRAND P. Le droit comparé, P., 4ème édition, R.2011.

6. Hamon F., Troper M. Droit constitutionnel.30e éd.; 2007, p. 79. Sm.: Toinbi A. Postizhenie istorii. M. 1991. S.73

7. Petrova G.V. Mezhdunarodnoe finansovoe pravo : ucheb. dlya vuzov. - M.: Yurait; Vysshee obrazovanie, 2009. - S. 15, 16.

8. Lisovskii V.I. Sushchnost' i sistema mezhdunarodnogo finansovogo prava // Sov. ezhegodnik mezhdunarodnogo prava (19641965). - M.: Nauka, 1966. - S. 134, 135.

9. Lisovskii V.I. Mezhdunarodnoe torgovoe i finansovoe pravo. - M.: Vysshaya shkola, 1974.

10. Veral'skii M. Rets. na kn.: Shpiller G. Valyutnaya monopoliya i mezhdunarodnye finansovye otnosheniya // Finance. - 1963. - № 3.

11. Rovinskii E.A. K voprosu o predmete mezhdunarodnogo finansovogo prava // Trudy VYuZI. - M., 1967. - T. 9. Voprosy sovetskogo finansovogo prava.

12. Rovinskii E.A. Mezhdunarodnye finansovye otnosheniya i ikh pravovoe regulirovanie // Sov. gosudarstvo i pravo. - 1965. - № 2. - S. 60-68.

13. Vinnitskii D.V. Mezhdunarodnoe dogovorno-pravovoe regulirovanie i sovremennoe byudzhetnoe pravo // Ocherki byudzhetnopravovoi nauki sovremennosti: monografiya / pod obshch. red. E.Yu. Grachevoi i N.P. Kucheryavenko. - M.; Khar'kov, 2009.

14. Al'tshuler A.B. Mezhdunarodnoe valyutnoe pravo. - M: Mezhdunarodnye otnosheniya, 1984.

15. Popondopulo V.F. Mezhdunarodnoe kommercheskoe pravo. - SPb., 2004.

16. Vel'yaminov G.M. Mezhdunarodnoe ekonomicheskoe pravo i protsess (Akademicheskii kurs) : ucheb. - M.: Volters Kluver, 2006.

17. Shumilov V.M. Mezhdunarodnoe finansovoe pravo : ucheb. - 2-e izd. - M.: Mezhdunarodnye otnosheniya, 2011. - S. 27.

18. Petrova G.V. Mezhdunarodnoe finansovoe pravo : ucheb. dlya vuzov. - M.: Yurait; Vysshee obrazovanie, 2009. - S. 17.

19. Shumilov V.M. Mezhdunarodnoe ekonomicheskoe pravo : ucheb. - metod. posobie. 2-e izd. - M.: OOO IKK «DeKA», $2002 .-$ S. 42.

20. Rukavishnikova I.V. Metod finansovogo prava : avtoref. dis. ... d-ra yurid. nauk. - Saratov, 2004.

21. El'kind P.S. Sushchnost' sovetskogo ugolovno-protsessual'nogo prava. - LGU, 1963. - S. 91, 92.

22. Alekseev S.S. Vyrazhenie osobennostei predmeta sovetskogo grazhdanskogo prava v metode grazhdansko-pravovogo regulirovaniya. Vidy grazhdansko-pravovykh otnoshenii i metod grazhdansko-pravovogo regulirovaniya // V kn.: Antologiya ural'skoi tsivilistiki. 1925-1989 : sb. st. - M., 2001. - S. 155, 156.

23. Protasov V.N. Chto i kak reguliruet pravo : ucheb. posobie. - M, 1995. - S. 40.

24. Sandrovskii K.K. Tamozhennoe pravo. - Kiev, 1974. - S. 19.

25. Bakaeva O.Yu., Matvienko G.V. Tamozhennoe pravo : ucheb. / otv. red. N.I. Khimicheva. - M., 2004. - S. 27 (avtor glavy O.Yu. Bakaeva). 
DOI: $10.7256 / 1811-9018.2015 .8 .15673$

При цитировании этой статьи сноска на dоі обязательна

Теория

26. Markov L.N. Tamozhennoe pravo SSSR. - Irkutsk, 1973. - S. 24, 25.

27. Bakhrakh D.N., Kivalov S.V. Tamozhennoe pravo Rossii. - Ekaterinburg, 1995. - S. 6, 7.

28. Astafurov N.V. Pravovoe regulirovanie gosudarstvennykh i munitsipal'nykh raskhodov : dis. ... kand. yurid. nauk. - Volgograd, 2009.

29. Tsyrenzhapov Ch.D. Pravovye osnovy gosudarstvennykh i munitsipal'nykh raskhodov : dis. ... kand. yurid. nauk. - Tomsk, 2005.

30. Nersesyants V.S. Filosofiya prava. - M., 2006. - S. 33.

31. Efimova L.G. Bankovskoe pravo : ucheb. i prakt. posobie. - M.: Izd-vo «BEK», 1994. - S. 4, 5.

32. Egorova L.Yu. Problemy zashchity publichnykh interesov prokurorom v grazhdanskom i arbitrazhnom sudoproizvodstve : dis. ... kand. yurid. nauk. - M., 2006. - S. 46.

33. Sofienko M.B. Pravovaya svoboda kak sposob realizatsii individual'noi svobody v sotsial'noi sisteme : dis. ... kand. filos. nauk. - Tomsk, 2007. - S. 28-30.

34. Makinder Kh.Dzh. Geograficheskaya os’ istorii // Polis. - 1995. - № 4.

35. Rattsel' F. Chelovechestvo kak yavlenie zhizni // V kn.: Istoriya chelovechestva. - SPb., 2003. - S. 108, $138-153$.

36. Ershov V.V., Ashmarina E.M., Kornev V.N. Ekonomicheskoe pravo i ekonomicheskaya teoriya // Gosudarstvo i pravo. - 2015. № 1. - C. 57-71.

37. Ershov V.V., Ashmarina E.M., Kornev V.N. Ekonomicheskoe pravo: sravnitel'no-pravovoi analiz Germanii, Frantsii, Kitaya i Rossii // Gosudarstvo i pravo. - 2014. - № 9. - C. 53-64.

38. Shumilov V.M. Mezhdunarodnoe finansovoe pravo : ucheb. - M.: Mezhdunarodnye otnosheniya, 2005. - S. $42-45$.

39. Shumilov V.M. Mezhdunarodnoe finansovoe pravo : ucheb. - 2-e izd. - M.: Mezhdunarodnye otnosheniya, 2011. - S. 100. 